\title{
Homelessness: An Emerging Threat
}

\author{
Arulmani Thinagarajan', Sudip Bhattacharya², Kanica Kausha \\ ${ }^{1} \mathrm{MPH}$, Public Health Consultant, SRMIST, School of Public Health, Chennai. \\ ${ }^{2,3} \mathrm{MD}$ (Community Medicine), Senior Resident, PGIMER, Chandigarh. \\ DOI: https://doi.org/10.24321/2455.9199.201808
}

\section{Abstract}

Homelessness is a global burden. It is estimated that 100 million people are homeless worldwide according to United Nation estimates in the year of 2005. It is a major issue in developing nation such as India. The 2011 census counts there are 449,761 houseless households/ families and 17,73,040 homeless people in India - $52.9 \%$ in urban areas, and $47.1 \%$ in rural areas. Homelessnesss is multifactorial in origin. Some of common reasons are poverty, drug addiction, natural disaster and war, family problem and unemployment. Homeless people are very fragile, physically and mentally, they prone to victim of physical and social assault. We need to recognize homelessness as a major public health problem and attempt to target this group for special care in order to promote equity in health system as part of Sustainable Development Goals. The Government should undertake physical upgradation of informal settlements including different types of slum areas; unidentified, identified, recognised, notified and unauthorised housing accompanied by the providing access to roads and basic amenities like electricity, water supply and sanitation.

Keywords: Homelessness, Sustainable Development Goals, United Nations

\section{Introduction}

Food, shelter and clothing are the three basic needs of every individual that is to be met on priority basis. Universal Declaration of Human Rights recognizes the right to housing as part of the right to an adequate standard of living. It states that:

"Everyone has the right to a standard of living, adequate for the health and well-being of himself and of his family, including food, clothing, housing and medical care and necessary social services; and the right to security in the event of unemployment, sickness, disability, widowhood, old age, lack of livelihood or other circumstances beyond his control. Universal Declaration of Human Rights, article 25 , para1". ${ }^{1}$

Home itself serves psychological needs by providing a sense of private space, social needs by providing a gathering area of mutual space for the family and sometimes as an economic need by functioning as a centre of commercial production.
Homelessness is about the loss of all of these. It is an isolating and destructive experience in which their security is at stake and homeless people are the most vulnerable and socially excluded section of our society. Homelessness is more than 'rooflessness'. ${ }^{2}$

\section{Global Burden}

It is very difficult to enumerate the number of homeless. Various strategies have been in place to count the same like one-night counts or point in time, extrapolations from partial counts, windshield street surveys, adaptations of area probability designs, service-based designs.

It is estimated that 100 million of people are homeless worldwide according to United Nation estimates in the year of 2005. Figuring out the accurate picture of homelessness is challenging one. Each country's definition of homelessness is different.

Homelessness is a major issue in developing nation such as India. The Universal Declaration of Human Rights defines

Corresponding Author: Dr. Sudip Bhattacharya, PGIMER, Chandigarh.

E-mail Id: drsudip81@gmail.com

Orcid Id: https://orcid.org/0000-0001-7935-9013

How to cite this article: Thiyagarajan A, Bhattacharya S, Kaushal K. Homelessness: An Emerging Threat. Int J HealthCare Edu \& Med Inform 2018; 5(2): 18-20. 
'homeless' as those who do not live in a regular residence due to lack of adequate housing, safety, and availability. ${ }^{3}$

The 2011 census counts there are 449,761 houseless households/families and 17,73,040 homeless people in India - $52.9 \%$ in urban areas and $47.1 \%$ in rural areas - on the basis of a definition that identifies a person or family as homeless if they do not live in a 'census house,' which refers to a 'structure with roof.' Based on this definition, census officials instruct enumerators to visit places where the houseless population is likely to live - roadsides, pavements, near drainage pipes, under staircases, temple mandaps and railway stations. ${ }^{4}$

Due to the lack of clarity in the current definition, people who sleep in places where they work, for instance, are not counted as homeless, like labourers on construction sites, which arguably comprise a sizeable share of the working homeless population in cities. One challenge for policymakers is to define homelessness in a way that reflects the conditions in which people on the streets and in shelters live. The other is for the central and state governments to respond to the needs of these people with proper services and infrastructure on the basis of information on trends on urban and rural homelessness that is already in the hands of policymakers.

\section{Factors Responsible for Homelessness}

They include:

- Poverty: Homelessness and poverty are attached together. Poor people are not in a position to pay for housing, food, child care, health care, and education.

- Drug Addiction: Drug addiction and its consequences may lead to homelessness and opposite is also true.

- War and natural disasters: These are the common reasons of unexpected homelessness.

- Unhealthy relationships: Unhealthy relationships, persons raised in the problematic families are prone to homelessness. It is frequently seen between young people and their parents or guardians.

- Unemployment: It is also common. Unemployment leads to frustration among young generations and they used to become lost to avoid social and cultural pressure in their native place.

Homeless persons are varied in terms of their age-group, gender, livelihoods, place of origin and the reasons for living in the street.

Furthermore, there is a high proportion of mentally ill and street children in the homeless population. ${ }^{5}$ There are 18 million street children in India, the largest number of any country in the world, with 11 million being urban. ${ }^{5}$ Finally, more than three million men and women are homeless in
India's capital city of New Delhi. A family of four members has an average of five homeless generations in India. ${ }^{1}$

Migrants looking for employment to increase their better living standards were growing rapidly who are directly joining India's homeless population. Despite the efforts taken by the non-governmental organization concerning the same, these organizations are not adequate enough to tackle the problem. ${ }^{6}$

\section{Possible Solutions and Way Forward}

A strong culminating strategy to address the issue of homeless population and to sustain their well-being through proper channels of government and non-governmental organizational powers and policies. As per the article on morbidity and mortality of Homeless individuals published in Lancet, the extreme health inequity identified among the homeless people requires thorough inter-sectoral policy and service action to prevent marginalization. ${ }^{7,8}$

We need to recognize homelessness as a public health problem and attempt to target this group for special care in order to promote equity in health system. Finland is the only country in Europe where the number of homeless people has declined in recent years. Finland has eradicated rough sleeping and sustainably housed a significant number of long-term homeless people. Government of India is determined to provide shelter to all homeless by the year 2022. ${ }^{9}$ The Government should undertake physical upgradation of informal settlements including different types of slum areas; unidentified, identified, recognised, notified and unauthorised housing accompanied by the providing access to roads and basic amenities like electricity, water supply and sanitation. ${ }^{9-11}$

\section{Conflict of Interest: None}

\section{References}

1. Sattar S. Homelessness in India. Shelter - Hudco Publication 2014;15: 9-15.

2. Peressini T, Mcdonald L, Hulchanski JD. Towards a strategy for counting the homeless. In: Hulchanski JD, Campsie P, Chau S, et al. (eds.) Finding home: policy options for addressing homelessness in Canada (e-book). Cities Centre, University of Toronto, Toronto. 2010.

3. Goel G, Ghosh P, Ojha MK, et al. Urban homeless shelters in India: Miseries untold and promises unmet. Cities 2017; 71: 88-96.

4. India Homeless Resource Network [Internet]. [cited 2018 Aug 15]. Available from: http://www.ihrn. org.in/blog/Why-Re-defining-Homelessness--andResponding-to-Census-Data-Should-Inform-HomelessPolicy-in-India. 
5. Kelly BD. Mental health, mental illness, and human rights in India and elsewhere: What are we aiming for? Indian J. Psychiatry 2016; 58: 168.

6. Mathur M, Rathore $P$, Mathur M. Incidence, type and intensity of abuse in street children in India. Child Abuse \& Neglect 2009; 33: 907-13.

7. 5.3 lakh families in the country are homeless: Maken - Indian Express. Available from: http://archive. indianexpress.com/news/5.3-lakh-families-in-thecountry-are-homeless-maken/1084676/. Accessed on: 07-Jun-2018.

8. Aldridge RW, Story A, Hwang SW, et al. Morbidity and mortality in homeless individuals, prisoners, sex workers, and individuals with substance use disorders in high-income countries: a systematic review and meta-analysis. Lancet 2018; 391: 241-50.

9. Health of the homeless (editorial). The Lancet 2014; 384: 1478.

10. Hwang SW, Burns T. Health interventions for people who are homeless. The Lancet 2014; 384: 1541-7.

11. Fazel S, Geddes JR, Kushel M. The health of homeless people in high-income countries: descriptive epidemiology, health consequences, and clinical and policy recommendations. The Lancet 2014; 384: 152940.

Date of Submission: 2018-07-31 Date of Acceptance: 2018-o8-o8 